Published article: https://doi.org/10.1016/j.jclepro.2019.118376

\title{
Carbon footprint and land use of oat and faba bean protein concentrates using a life cycle assessment approach
}

\author{
(Heusala, Hannele ${ }^{1 *}$, Sinkko, Taija, ${ }^{1}$, Sözer, Nesli, ${ }^{2}$, Hytönen, Eemeli ${ }^{2}$, Mogensen, Lisbeth ${ }^{3}$ \& \\ Knudsen, Marie Trydeman ${ }^{3}$ \\ ${ }^{1}$ Natural Resources Institute Finland, POB 2, FI-00791 Helsinki, Finland \\ ${ }^{2}$ VTT Technical Research Centre of Finland Ltd, POB 1000, FI-02044 VTT, Finland \\ ${ }^{3}$ Aarhus University, Department of Agroecology, Blichers Allé 20, DK-8830 Tjele, Denmark \\ *Corresponding author, Hannele.heusala@luke.fi , +358295326446
}

\section{Highlights}

- Carbon footprints and land use of oat and faba bean protein concentrates were assessed using LCA.

- Carbon footprint per kg protein of the oat and faba bean protein concentrates are less than half of dairy proteins.

- Plant proteins have potential to reduce environmental impacts of food consumption.

- Benefits are achieved despite the energy required in processing of beta glucan processing co-products to protein products.

\begin{abstract}
There is a need to find sustainable alternative protein sources in order to meet the increasing protein demand of the growing population. Legumes such as faba beans are underutilized protein rich sources and can be valorized as hybrid protein ingredient through dry fractionation technologies. Also, cereal side streams can be interesting sources towards multifunctional protein ingredients.

The aim of this study was to assess the environmental impacts of the production of oat protein concentrate (OPC) and faba bean protein concentrate (FBC) using life cycle assessment (LCA) methodology and to compare the impact per kg protein to other relevant proteins. The OPC is obtained as a side stream of the beta glucan extraction process, which also produces valuable oat oil, while FBC is the only main product obtained from dehulled faba beans. Average European oat cultivation and faba bean cultivation with low and high yield were modelled. Data for protein concentrates production was from real factories who have suitable facilities, but are not currently producing concentrates commercially.

The major hotspot in the carbon footprint of oat protein concentrate comes from energy consumption in processing. For faba bean protein concentrate, energy consumption in processing is lower and cultivation of faba bean is the main hotspot.
\end{abstract}


The carbon footprint of oat protein concentrate is more than 50 percent lower, compared to dairy proteins per $\mathrm{kg}$ protein, while the carbon footprint of faba bean concentrate protein is 80-90 percent lower. Compared to legume protein sources, OPC has four times higher impacts. This is mainly due to the lower amount of processing steps needed to reach high protein content concentrates from faba beans resulting mainly from relatively lower level of lipids, which enables more energy-efficient dry separation, and high initial protein content of legumes compared to cereals. Moreover, legume cultivation requires very little nitrogen fertilizers due to symbiotic $\mathrm{N}_{2}$ fixation.

This study shows that OPC and FBC have lower carbon footprints than animal protein sources. However, it should be remembered, that the environmental impacts of OPC are very sensitive to the allocation method and allocation basis. In this study economic allocation was used and prices of the different products (OPC, oat oil and beta glucan) play a key role in defining the climate impacts of OPC.

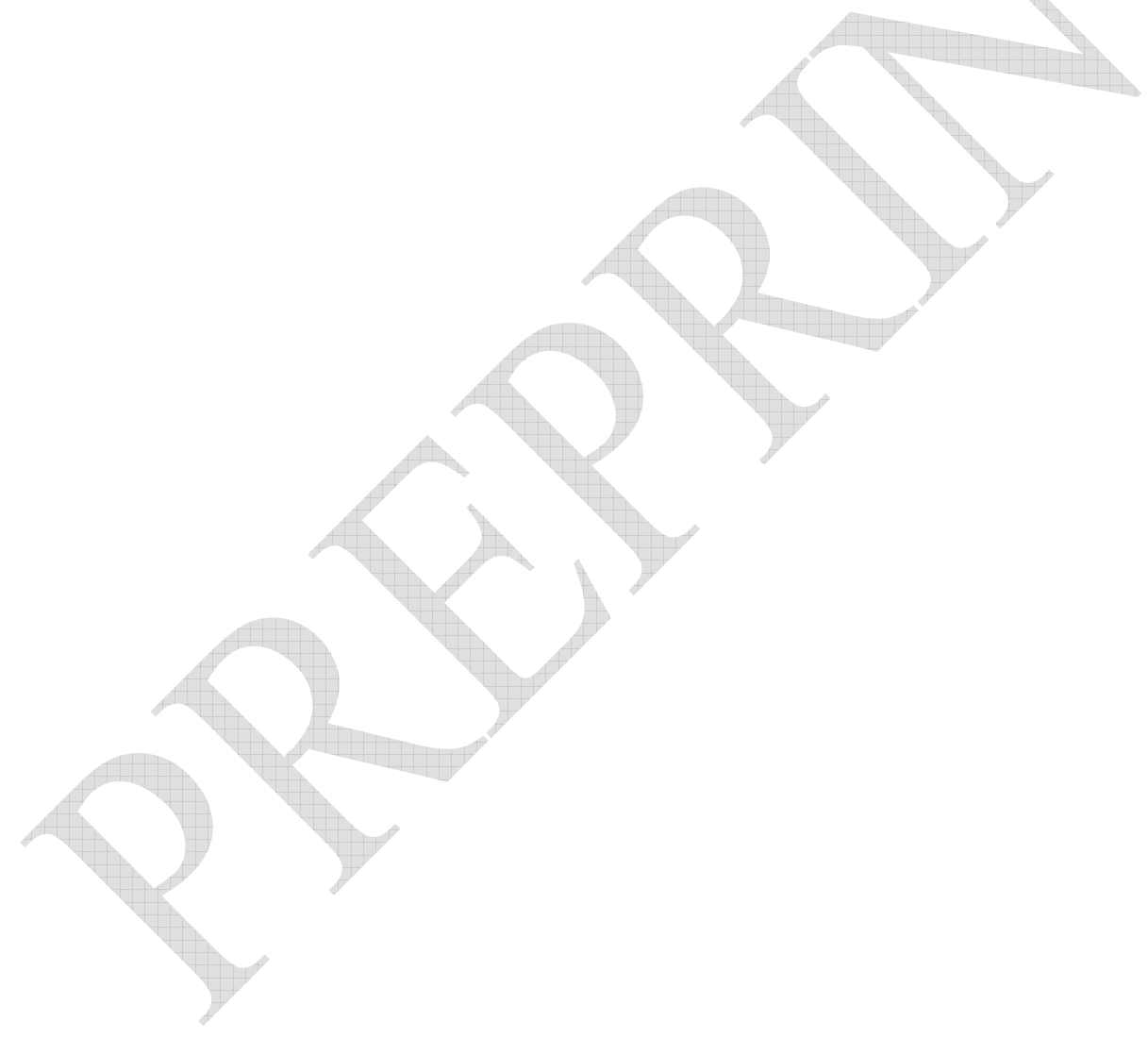




\section{Introduction}

Food production and consumption are responsible for around $25 \%$ of the carbon footprint of the total consumption in Europe (Tukker et al., 2006) and of several other environmental impacts, such as eutrophication, land use etc. (Xue \& Landis, 2010). Many studies show that plant-based food products have lower land use, and lower impact on climate and eutrophication compared to animal-based food products (e.g. Carlsson-Kanyama \& Gonzalez 2009, Nijdam et al. 2012, Xue \& Landis 2010). Plant proteins such as peas and beans, have the lowest land use per kg protein followed by protein from milk, eggs and poultry. The land use per kg pork protein is approximately twice as high and more than seven times higher per $\mathrm{kg}$ beef protein compared to per kg plant protein (Nijdam et al. 2012). On average, the production of $1 \mathrm{~kg}$ animal based protein needs an input of $10 \mathrm{~kg}$ plant proteins, depending on meat production type (Reijnders \& Soret, 2003). Environmental impacts in animal production are higher than in plant production due to direct emissions from animals, in particularly from enteric fermentation of ruminants and manure management, and due to high feed consumption per $\mathrm{kg}$ meat produced. There is an increasing pressure to find alternative sustainable protein sources to meet the protein demands of the growing global population despite the limited agricultural land.

Therefore, from an environmental point of view there is a need to consume less animal-based proteins and increase the intake of plant-based proteins. Also from a health perspective, a shift from animal-based to plant-based protein consumption would be favourable in Western countries where current red meat consumption levels are increasing the risk of cancers (WCRF, 2017). However, the increasing elderly population requires elevated protein intake to maintain good health (Nowson \& O'Connell, 2015).

Availability of sustainable plant protein sources could be increased by finding novel protein sources or by efficient valorisation of the existing ones. Side-streams from cereal processing are under-exploited despite their high content of health promoting valuable components such as dietary fibre, protein and bioactive compounds (Sozer et al. 2017a). Valorising sidestreams also has the potential of providing protein sources with low carbon footprint, because the main product will bear the main environmental burden of the production and the sidestream (or waste stream) will mainly only bear the environmental impact from the valorisation and further processing.

The most commonly used plant proteins in food applications are from soy, wheat, pea, rice and canola (Nehete et al., 2013; Frost \& Sullivan, 2016a and 2016b). However, to increase the amount of available and sustainable plant protein sources, diverse alternative plant protein sources are needed. There is a need to find suitable and more sustainable protein sources with different properties for different food applications. One way to do this is to develop new legume products and to valorise existing side streams more efficiently.

Oat is an important crop worldwide with a global production of 21 million ton per year hereof $62 \%$ in the EU (FAOSTAT, 2012). In EU-27, the top three oat producers are Poland, Finland 
and Germany. Oats are mainly used as feed for livestock; i.e. about 50\% is fed for cattle, and less than $10 \%$ is used for food products.

Some oats are also further processed for the very valuable products, beta glucan and oat oil, where a side-stream of this process is also containing a protein rich fraction. The overall concept for producing oat based protein concentrate evaluated in this work is based on a patent by Kaukovirta-Norja et al. (2008). This concept focuses on dry separation of oat betaglucan where a side stream rich in proteins could also be obtained, and can therefore contribute to wider applications for oats. However, this protein rich fraction can be used as a valuable protein ingredient either to replace animal proteins or to enrich the protein content in traditional foods e.g. bread and pasta. Furthermore, it is of particular interest as it has the potential of being gluten-free, as long as contamination can be controlled in the whole production chain (Mäkinen et al., 2016).

In recent years, there has been a growing interest for increasing the amount of legumes in the diet. Faba bean (Vicia faba L.) is an annual legume growing in different climatic zones from Europe to Africa and Asia. Faba bean seeds are rich in proteins, vitamins, minerals and dietary fibre (Coda et al. 2015). Faba bean can be further processed to obtain a protein rich fraction, which can be used as a hybrid ingredient either to replace animal proteins in foods or to produce protein-enriched foods (Sozer et al., 2017b).

There are very few published studies on environmental impacts of plant proteins. Deng et al. (2013) have studied wheat gluten as an ingredient in packaging industry, and Smetana et al (2015), have studied gluten and soy meal based meat alternatives. A few references can also be found from the Agri-Footprint database (Blonk Agri-footprint, 2014) and Thrane et al. (2016) for soy, potato and pea concentrates and soy and gluten isolates, and in Finnigan (2010) for mycoprotein. Those studies indicate that nitrogen fixing legumes and concentrates of them are very environmentally friendly as protein sources. Although it should be remembered that soy cultivation causes significant land use changes in certain regions and if the greenhouse gas emissions related to deforestation would be included in assessments, the impacts of soy concentrates would be much higher. The sustainability of the new protein concentrates from oat and faba bean needs to be evaluated and compared with other protein sources to investigate their potential to help mitigate GHG emissions from food consumption.

Life cycle assessment (LCA) is one of the most widely used methods to assess the environmental impact of a product throughout the life cycle of the product (Notarnicola et al., 2017) and is recognised by the European Commission as the best method for environmental assessment of a product (European Commission, 2013).

The aim of this study was therefore to assess the carbon footprint and land use in the production of oat protein concentrate (OPC) and faba bean protein concentrate (FBC) using the life cycle assessment (LCA) methodology and to compare the impact per kg protein to other relevant proteins, such as soy, wheat, pea and dairy proteins. The OPC is obtained from a side stream of beta glucan extraction system, which also produces valuable oat oil 
(Kaukovirta-Norja et al., 2008), while FBC is the main product obtained from dehulled and milled faba beans by dry separation (Coda et al., 2015).

\section{Material and methods}

A life cycle assessment (LCA) approach was used in the present study, that cover the chain until factory gate where the protein concentrates are assumed to be produced. Modelling was done with SimaPro 8.4. tool. Environmental impact categories included in this study were carbon footprint (global warming potential, GWP) and land use. For estimating carbon footprint, IPCC 2013 characterization factors with a time frame of 100 years as implemented by Pré Consultants in Simapro were used. Thus, the characterization factor for biogenic methane was 27.75 , fossil methane 30.5 , carbon dioxide 1 and dinitrogen monoxide 265 . For land use, only the use of agricultural land in cultivation was taken into account, not area used for production plants.

\subsection{Goal and scope}

\section{Functional unit}

The functional unit was $1 \mathrm{~kg}$ oat protein concentrate (with $37 \%$ of protein) and $1 \mathrm{~kg}$ faba bean protein concentrate (with $60 \%$ of protein). In addition to the results per $\mathrm{kg}$ product, the results were shown per kg protein from the oat or faba bean concentrates.

\section{System boundary}

All relevant processes related to production of oat and faba bean protein concentrates were included in the study. Figure 1 presents the processes in the production of the concentrates from the cultivation of the crops to the processing steps. From the cultivation of oats and faba beans, the production of all relevant inputs, e.g. fertilizers, lime, fuels, and transport of inputs and emissions related to cultivation were included in the assessment. The assessment included also all energy and other inputs needed in the processing of the protein concentrates and transportation of the raw materials. According to the Danish cultivation data, the carbon footprint of pesticide production accounted only for $3 \%$ of carbon footprint of Danish crop production (Audsley et al. 2009). Thus, production of pesticides was excluded from the study. Also production of machines and infrastructure were excluded from the main processes. 
PRODUCTION OF OAT PROTEIN CONCENTRATE

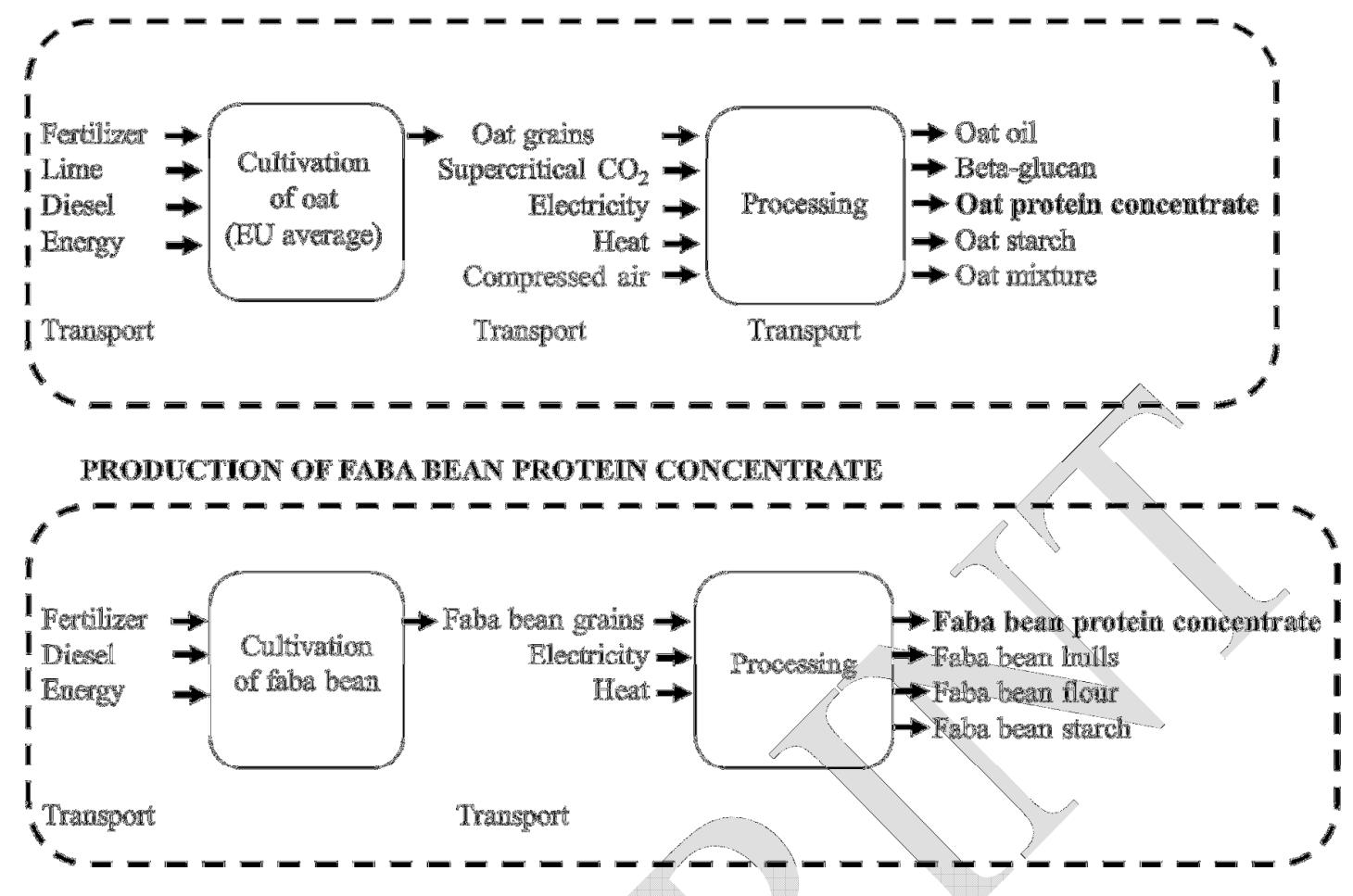

Figure 1. System boundaries in production of oat and faba bean protein concentrates.

The production of oat protein concentrate (OPC) is presented in Kaukovirta-Norja et al. (2008): After dehulling and flaking or roller milling, oats are defatted using supercritical- $\mathrm{CO}_{2}$ extraction. In the second phase, defatted oat flour is milled and air classified twice to separate beta glucan, oat protein, oat starch and oat mixture (Figure 1).

Faba bean concentrate production includes cracking the seeds, de-hulling, milling and air classification which separate starch and protein rich fractions (Coda et al. 2015) (Figure 1).

\subsection{Life Cycle Inventory}

\subsubsection{Oat Cultivation data}

In order to find the average oat produced and sold in Europe, the major oat export countries in Europe were identified, which were Finland, Sweden, France, Poland, Germany, Spain, UK and Denmark (FAOSTAT, 2017). These countries represent almost $80 \%$ of all exported oat in Europe (FAOSTAT, 2017). However, oat cultivation input-output data was not available from all countries, thus some countries were assumed to represent also other country with similar yield, e.g. cultivation in Finland also represent cultivation in Sweden, and together these two productions represent $68 \%$ of European oat export (Table 1).

Conventional oat cultivation was considered in all countries. Input and output data used for the five countries is shown in Table 1. Assessment of environmental impacts of cultivation was conducted separately for each country, and the average EU values are shown here only for illustrative purposes. 
Table 1. Main input output data used in assessment of oat cultivation in different countries.

\begin{tabular}{|c|c|c|c|c|c|c|}
\hline $\begin{array}{l}\text { Countries used in assessment } \\
\text { Countries represented } \\
\text { Proportion in assessment }\end{array}$ & $\begin{array}{r}\text { Finland } \\
(\mathrm{FI} \& \mathrm{SE}) \\
68 \% \\
\end{array}$ & $\begin{array}{r}\text { Denmark } \\
(\mathrm{DK} \& \mathrm{FR}) \\
12 \%\end{array}$ & $\begin{array}{r}\text { Germany } \\
\text { (DE \& UK) } \\
9 \% \\
\end{array}$ & $\begin{array}{r}\text { Romania } \\
(\mathrm{RO} \mathrm{\&} \mathrm{ES)} \\
5 \% \\
\end{array}$ & $\begin{array}{r}\text { Poland } \\
\text { (only PO) } \\
6 \% \\
\end{array}$ & Average EU \\
\hline $\begin{array}{l}\text { Input } \\
\text { Mineral } \mathrm{N} \text { fertilizer }\left(\mathrm{kg} \mathrm{N} \mathrm{ha}^{-1}\right) \\
\text { Lime }\left(\mathrm{kg} \mathrm{ha}{ }^{-1}\right) \\
\text { Fuel consumption }\left(\mathrm{lha}^{-1}\right)\end{array}$ & $\begin{array}{r}83^{1} \\
139^{1} \\
65^{2}\end{array}$ & $\begin{array}{r}91^{4} \\
165^{5} \\
67^{2}\end{array}$ & $\begin{array}{r}80^{7} \\
167^{8} \\
66^{2}\end{array}$ & $\begin{array}{r}42^{9} \\
150^{10} \\
64^{2}\end{array}$ & $\begin{array}{r}55^{11} \\
150^{10} \\
64^{2}\end{array}$ & $\begin{array}{r}80 \\
146 \\
65\end{array}$ \\
\hline $\begin{array}{l}\text { Output } \\
\text { Oat grain yield }\left(\mathrm{kg} \mathrm{ha}^{-1}\right)\end{array}$ & $3743^{1}$ & $4936^{3}$ & $5010^{6}$ & $1973^{9}$ & $2731^{3}$ & 3851 \\
\hline $\begin{array}{l}{ }^{1} \text { SustFoodChoice -project in Luke, bas } \\
{ }^{2} \text { Number of field operations (Anonym, } \\
3 \text { FAOSTAT } 2017 \\
{ }^{4} \text { Danish norms (Anonym, 2014) } \\
5 \text { Nielsen et al. } 2014 \\
{ }^{6} \text { Statistics Germany, } 2014 \\
7{ }^{7} \text { Bavarian State Research Institute for } \\
{ }^{8} \text { KTBL } \\
{ }^{9} \text { TEMPO database } \\
10 \text { Expert opinion } \\
{ }^{11} \text { Estimated according to FAO } 2003\end{array}$ & $\begin{array}{l}\text { ProAgria dat } \\
\text { 1), fuel use pe } \\
\text { ulture }\end{array}$ & $\begin{array}{l}\text { (not published p } \\
\text { operation (Dalga }\end{array}$ & $\begin{array}{l}\text { eviously) } \\
\text { rd et al. 2002) }\end{array}$ & & & \\
\hline
\end{tabular}

The same level of fuel consumption in field work was assumed across countries based on similar field operations and same fuel consumption per operation. Thus, the only difference between countries in fuel consumption is because of different yield, as fuel consumption in harvesting is dependent on the yield. The straw yield was estimated according to IPCC (2006), and straw was assumed to be left on field, except in Denmark where 9\% of the straw yield was assumed to be collected and sold for energy production. Energy consumption for irrigation and drying was taken into account in those countries that need to use irrigation (Denmark and Germany) and to dry grains for storage (Finland, Denmark and Poland). Emissions from peat land cultivation were included to the assessment in those countries that use peat lands for cultivation (Finland and Romania).

\subsubsection{Faba bean cultivation data}

Faba bean cultivation was modelled using same methodology as oat cultivation. However, it was not possible to estimate an EU average faba bean due to lack of cultivation data. The major faba bean exporting countries in years 2009-2013 in Europe were France, United Kingdom, Germany, Spain and Italy (FAOSTAT 2017). Due to lack of cultivation input data from these major export countries, it was decided to assess faba bean cultivation as low and high yield scenarios based on Knudsen et al. (2013). Yield in high yield scenario is similar to yields in France and Germany, and yield in low yield scenario has similar yield as it is in Spain and Italy (Table 2 and FAOSTAT 2017).

Table 2. Main input output data used in assessment of faba bean cultivation in low and high yield scenarios (Knudsen et al. 2013).

\begin{tabular}{lrr}
\hline FABA BEAN CULTIVATION & Low yield & High yield \\
\hline Input & & \\
Mineral N fertilizer $\left(\mathrm{kg} \mathrm{N} \mathrm{ha}^{-1}\right)$ & 0 & 0 \\
Mineral P fertilizer $\left(\mathrm{kg} \mathrm{P} \mathrm{ha}^{-1}\right)$ & 44 & 16 \\
Fuel consumption $\left(1 \mathrm{ha}^{-1}\right)$ & 45 & 47
\end{tabular}

Output 


\subsubsection{Processing and transport data}

Oat processing data was from two factories, which have the technology available and conducted the two phase processing to generate the fractions and data for the environmental analyses. However, those factories are currently not producing the oat protein commercially. More detailed description of the processing is reported in Kaukovirta-Norja et al. (2008). Summary of the inventory data relevant for carbon footprint assessment is presented in Table 3.

Table 3. Inventory data for the processing of oat protein concentrate. The amounts are given according the functional unit (FU) of $1 \mathrm{~kg}$ oat protein concentrate.

\begin{tabular}{lrl}
\hline OAT PROCESSING & Amount & Unit \\
\hline Input & & \\
Oat grains & 20.2 & $\mathrm{~kg} \mathrm{FU}^{-1}$ \\
Energy consumption & 114.7 & $\mathrm{kWh} \mathrm{FU}^{-1}$ \\
Supercritical $\mathrm{CO}_{2}{ }^{*}$ & - & $\mathrm{kg} \mathrm{FU}^{-1}$ \\
Compressed air* & - & $\mathrm{kg} \mathrm{FU}^{-1}$ \\
Transport & $11.9 \mathrm{tkm} \mathrm{FU}$ \\
Output & & \\
Oat protein concentrate & $1.0 \mathrm{~kg}$ \\
Oat oil & 0.9 & $\mathrm{~kg} \mathrm{FU}^{-1}$ \\
Beta-glucan & $1.6 \mathrm{~kg} \mathrm{FU}^{-1}$ \\
Oat starch & $14.4 \mathrm{~kg} \mathrm{FU}^{-1}$ \\
Oat mixture & $1.3 \mathrm{~kg} \mathrm{FU}^{-1}$ \\
\hline$*$ Amout is confidial
\end{tabular}

* Amount is confidential and cannot be published

Faba bean processing data was provided by VTT and reported more in detail in Coda et al. (2015). Summary of the inventory data relevant for carbon footprint assessment is presented in Table 4Table 3.

Table 4. Inventory data for the processing of faba bean protein concentrate. The amounts are given according the functional unit (FU) of $1 \mathrm{~kg}$ faba bean protein concentrate.

\begin{tabular}{lrr}
\hline FABA BEAN PROCESSING & Amount & Unit \\
\hline Input & & \\
Faba bean grains & 4.3 & $\mathrm{~kg} \mathrm{FU}^{-1}$ \\
Energy consumption & 1.1 & $\mathrm{kWh} \mathrm{FU}^{-1}$ \\
Transport & 2.1 & $\mathrm{tkm} \mathrm{FU}^{-1}$ \\
Output & & \\
Faba bean concentrate & 1.0 & $\mathrm{~kg}$ \\
Faba bean flour & 0.2 & $\mathrm{~kg} \mathrm{FU}^{-1}$ \\
Faba bean starch & 2.0 & $\mathrm{~kg} \mathrm{FU}^{-1}$ \\
Faba bean hulls & 1.0 & $\mathrm{~kg} \mathrm{FU}^{-1}$ \\
\hline
\end{tabular}

Comparing inventory data for oat and faba bean processing, a larger amount of oat than faba bean is needed to produce $1 \mathrm{~kg}$ protein concentrate (Table 3 and Table 4), this is mainly 
because of lower protein content of oat. In addition, energy consumption per kg protein concentrate is higher when producing OPC than FBC. This is partly due to higher processing needs of obtaining all oat products. The main part of consumed energy in oat processing is coming from the supercritical $\mathrm{CO}_{2}$ extraction process.

Transportation of oat and faba bean was assumed to be only road transportation with truck. It was assumed that in the future there would be couple of such factories in central locations in Europe. Thus, the transportation distance from farm to processing was assumed to be $500 \mathrm{~km}$ for both oat and faba bean. However, OPC production is divided into two processing phases and these could be in different locations. Thus, in order to be sure not to underestimate the impacts, an additional intermediate product transportation of $100 \mathrm{~km}$ was included in the assessment.

\subsection{Emission factors}

Similar emission factors were used for modelling the emissions related to cultivation of oat and faba beans. Applied reference behind the emission factors are presented in Table 5.

Table 5. Main emission factors used in the assessment.

\begin{tabular}{|c|c|c|}
\hline & $\begin{array}{l}\text { Database or other } \\
\text { source }\end{array}$ & Process name in database \\
\hline $\begin{array}{l}\text { Nitrogen fertilizer } \\
\text { production }\end{array}$ & Agri-footprint & $\begin{array}{l}\text { Calcium ammonium nitrate (CAN), (NPK 26,5-0-0), at } \\
\text { regional storehouse/RER economic }\end{array}$ \\
\hline $\begin{array}{l}\text { Phosphorus fertilizer } \\
\text { production }\end{array}$ & Ecoinvent & $\begin{array}{l}\text { Triple superphosphate, as } \mathrm{P} 2 \mathrm{O} 5 \text {, at regional storehouse/RER } \\
\mathrm{S}\end{array}$ \\
\hline Lime production & Agri-footprint & Lime fertilizer, at regional storehouse/RER economic \\
\hline $\begin{array}{l}\text { Diesel production and use } \\
\text { in farm }\end{array}$ & Agri-footprint & Energy, from diesel burned in machinery/RER economic \\
\hline $\begin{array}{l}\text { Electricity production and } \\
\text { use in farm }\end{array}$ & Ecoinvent & Country specific, e.g. Electricity, low voltage, at grid/FI \\
\hline $\begin{array}{l}\text { Electricity production and } \\
\text { use in processing }\end{array}$ & Ecoinvent & Electricity, medium voltage, production RER, at grid \\
\hline $\begin{array}{l}\text { Heat production and use } \\
\text { for grain drying }\end{array}$ & Ecoinvent & $\begin{array}{l}\text { Light fuel oil, burned in industrial furnace } 1 \mathrm{MW} \text {, non- } \\
\text { modulating/RER } S\end{array}$ \\
\hline $\begin{array}{l}\text { Heat production and use } \\
\text { in processing }\end{array}$ & Ecoinvent & Heat, light fuel oil, at industrial furnace 1MW/RER \\
\hline Transportation & Agri-footprint & $\begin{array}{l}\text { Transport, truck > 20t, EURO4, 50\%LF, default/GLO } \\
\text { economic }\end{array}$ \\
\hline $\begin{array}{l}\text { Direct and indirect } \mathrm{N} 2 \mathrm{O} \\
\text { emissions }\end{array}$ & IPCC 2006 & - \\
\hline $\begin{array}{l}\text { NO3 leaching used for } \\
\text { indirect } \mathrm{N} 2 \mathrm{O} \text { emissions }\end{array}$ & $\begin{array}{l}\text { Nutrient balance } \\
\text { model }\end{array}$ & - \\
\hline Emissions from lime use & IPCC 2006 & - \\
\hline Emissions from peat soils & IPCC 2006 & - \\
\hline
\end{tabular}

\subsection{Allocation}

Economic allocation was used for allocating the environmental impacts on the single products. The fractions have very different properties and thus, different application and economic value. Therefore, economic allocation was seen most suitable, even though it was very challenging to quantify the market value of the products. For obtaining a representative market price range for each of the products, several publicly available sources were used; 
moreover, due to the diverse product portfolio all needed price data is not available in any single market study or data source. As one data source, Alibaba.com was used for defining the market price ranges of the main products: Inclusion criteria for considering an available product relevant for defining these ranges were a) the width of the price range reported and $b$ ) the overall price level. Very wide ranges and very high prices were excluded as they may imply many small shipments or very specialty products. After defining all price ranges, their average values were used to define allocation factors. All prices, allocation factors and sources are shown for oat fractions in Table 6 and and for faba bean fractions in Table 7.

Table 6. Estimated prices, allocation factors and their sources and justifications for oat fractions.

\begin{tabular}{|l|c|c|l|}
\hline & $\begin{array}{c}\text { Price } \\
\text { USD/kg }\end{array}$ & $\begin{array}{c}\% \text { of } \\
\text { income }\end{array}$ & Source and justification: \\
\hline Beta glucan & 10 & 45 & Alibaba (2018): expert judgement \\
\hline Oat oil & 10 & 25 & $\begin{array}{l}\text { Alibaba (2018): average of large scale oat oil and avocado } \\
\text { oil supply prices, price range 5-15USD/kg }\end{array}$ \\
\hline Oat protein & 2 & 5.6 & $\begin{array}{l}\text { Mulder et al. (2016), Frost\&Sullivan (2016b): plant proteins } \\
\text { (soy, pea, wheat gluten based) with 50-70\% protein content, } \\
\text { price range 1.4-2.5 USD/kg. Higher protein content } \\
\text { reference plant proteins and dairy proteins or possible added } \\
\text { value due to other functionalities is not considered in this } \\
\text { baseline analysis }\end{array}$ \\
\hline Oat starch & 0.6 & 24 & $\begin{array}{l}\text { Alibaba (2018), Elder M. (2017): calculated from world } \\
\text { market value and volume estimates for native starch }\end{array}$ \\
\hline Mix fraction & 0.1 & 0.4 & Estimated based on energy content \\
\hline
\end{tabular}

Table 7. Estimated prices, allocation factors and their sources and justifications for faba bean fractions.

\begin{tabular}{|l|c|c|l|}
\hline & $\begin{array}{c}\text { Price } \\
\text { USD/kg }\end{array}$ & $\begin{array}{c}\text { \% of } \\
\text { income }\end{array}$ & Source and justification: \\
\hline $\begin{array}{l}\text { Protein-rich } \\
\text { fraction }\end{array}$ & 2.5 & 63 & $\begin{array}{l}\text { Mulder et al. (2016), Frost\&Sullivan (2016b): plant proteins } \\
\text { (soy, pea, wheat gluten based) with 50-70\% protein content, } \\
\text { price range 1.4-2.5 USD/kg. Higher protein content } \\
\text { reference plant proteins and dairy proteins or possible added } \\
\text { value due to other functionalities is not considered in this } \\
\text { baseline analysis }\end{array}$ \\
\hline Flour & 0.6 & 3.5 & Mulder et al. (2016), Marz U. (2013): Soy meal \\
\hline Starch-rich & 0.6 & 31 & $\begin{array}{l}\text { Alibaba (2018): Legume starch fractions; Mulder et al. } \\
\text { (2016), Marz U. (2013): Soy meal as reference with similar } \\
\text { protein content }\end{array}$ \\
\hline Hull & 0.1 & 2.5 & Estimated based on energy content \\
\hline
\end{tabular}

In the cultivation of oat, allocation between oat and straw was also made according to economic value as in Denmark 9\% of straw from oat cultivation is used for energy production (Danish Statistics, 2017). Values of oat and straw in Denmark were from FarmTal online (Anonymous, 2012). In the other countries, 100\% of the straw was assumed to be left on the field, and thus, no allocation was made. 


\section{Results}

\subsection{Oat and faba bean cultivation}

The carbon footprint of cultivation of EU average oat is $0.55 \mathrm{~kg} \mathrm{CO}_{2}$-eq. per $\mathrm{kg}$ oat, varying between 0.33 (in Germany) and 0.68 (in Romania) $\mathrm{kg} \mathrm{CO}_{2}$-eq. per $\mathrm{kg}$ oat (Figure 2). Oat cultivated in Germany has the lowest carbon footprint due to the highest yield. Romania has the highest carbon footprint because yield is lowest in Romania. There are also some peat lands in Romania in cultivation which are significant source of additional emissions. Finland has also a significant share of peat lands in cultivation, thus the carbon footprint of Finnish oat is almost as high as it is in Romania. Biggest contribution to carbon footprint is from nitrogen fertilizer production and use (field $\mathrm{N}_{2} \mathrm{O}$ emissions), and from energy consumption in field work.

Carbon footprint of faba bean cultivation is between 0.23 and $0.58 \mathrm{~kg} \mathrm{CO}_{2}$-eq. per $\mathrm{kg}$ faba bean when it was assumed that all faba beans are cultivated in mineral soils (i.e. no emissions from peat soil cultivation). Also, faba bean cultivation does not need any additional nitrogen fertilization, because faba bean is a nitrogen fixing plant. However, some nitrogen leaching and other nitrogen losses happen also in faba bean cultivation. This is included to the field $\mathrm{N}_{2} \mathrm{O}$ emissions. Others include e.g. seed and phosphorus fertilizer production. Land use of oat cultivation is between $2.0 \mathrm{~m}^{2}$ and $5.5 \mathrm{~m}^{2}$ per $\mathrm{kg}$ oat in different countries included to the assessment, and $2.8 \mathrm{~m}^{2}$ an average (Figure 2). Land use of faba bean cultivation is higher, an average $5.4 \mathrm{~m}^{2}$ per $\mathrm{kg}$ faba bean. It varies between 3.0 and $7.7 \mathrm{~m}^{2}$ per $\mathrm{kg}$ faba bean.

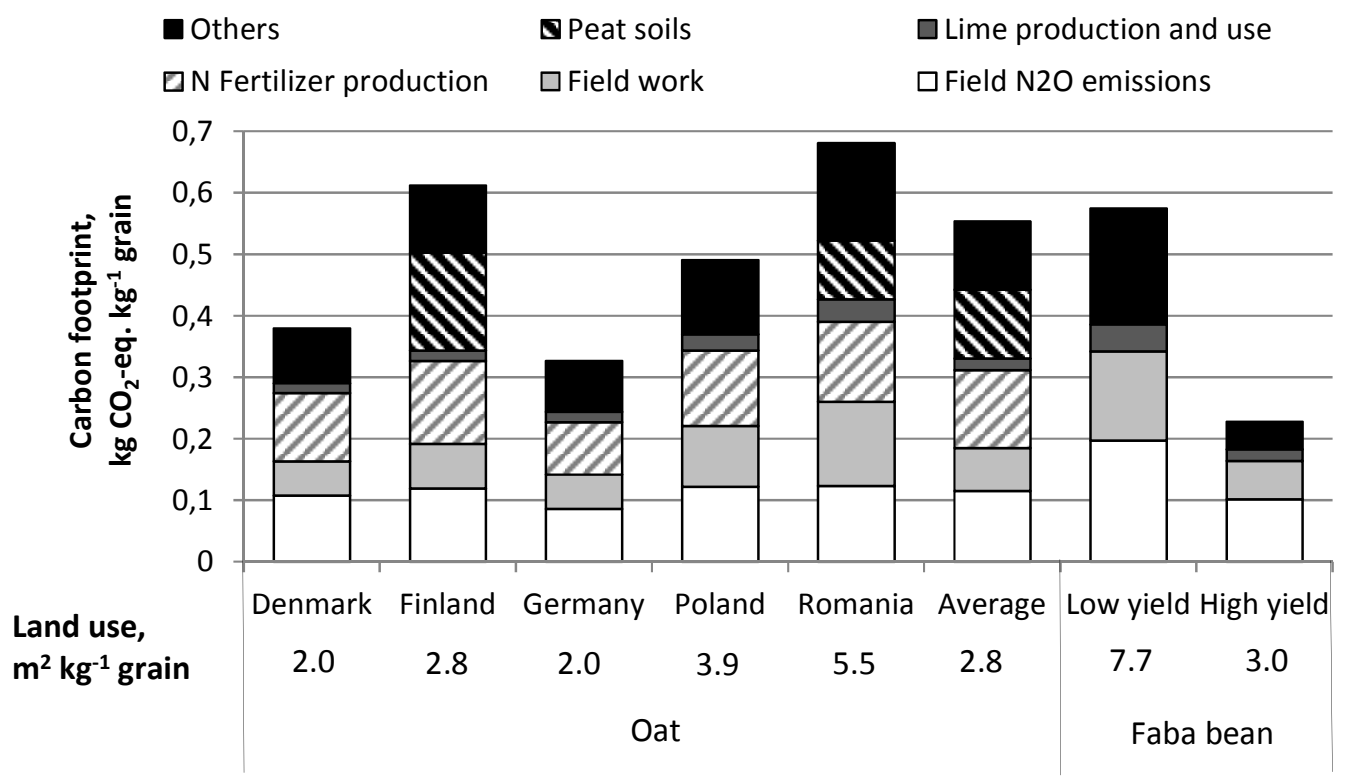

Figure 2. Carbon footprint and land use of oat cultivated in different countries, EU average oat, and faba bean cultivation in Europe either when yield is low or high.

\subsection{Oat and faba bean protein concentrates}


When assessing impact per kg product, carbon footprint of oat protein concentrate is higher compared to faba bean protein concentrate with both low and high faba bean yield (Table 8). When assessing per $\mathrm{kg}$ protein, faba bean has even lower impact due to higher protein content (60\% protein in FBC, 37\% protein in OPC). Land use of OPC is much smaller than land use of $\mathrm{FBC}$, because only small amount of oat cultivation impact is allocated to oat protein concentrate because oat oil (from processing 1) has high economic value, and also due to higher yield of oat compared to low yield faba bean.

Table 8. Environmental impacts of cradle-to-processing of oat protein concentrate and faba bean protein concentrate.

\begin{tabular}{lcccc} 
& \multicolumn{2}{c}{ Carbon footprint } & \multicolumn{2}{c}{ Land use } \\
\cline { 2 - 5 } & $\begin{array}{c}\mathrm{kg} \mathrm{CO}_{2} \text { eq } \\
\mathrm{kg}^{-1} \text { concentrate }\end{array}$ & $\begin{array}{c}\mathrm{kg} \mathrm{CO}_{2} \mathrm{eq} \\
\mathrm{kg}^{-1} \\
\text { protein }\end{array}$ & $\begin{array}{c}\mathrm{m}^{2} \\
\mathrm{~kg}^{-1} \\
\text { concentrate }\end{array}$ & $\begin{array}{c}\mathrm{m}^{2} \\
\mathrm{~kg}^{-1} \\
\text { protein }\end{array}$ \\
\hline $\begin{array}{l}\text { Oat protein concentrate } \\
\text { (OPC), EU average }\end{array}$ & 3.3 & 8.8 & 3.2 & 8.6 \\
$\begin{array}{l}\text { Faba bean protein } \\
\text { concentrate (FBC), low yield }\end{array}$ & 2.0 & 3.4 & 20.8 & 34.7 \\
$\begin{array}{l}\text { Faba bean protein } \\
\text { concentrate (FBC), high yield }\end{array}$ & 1.1 & 1,9 & 8.0 & 13.3 \\
\hline
\end{tabular}

The major hotspot in the carbon footprint of oat protein concentrate comes from energy consumption in processing of oat (Figure 3). For faba bean protein concentrate, energy consumption in processing is lower and thus, cultivation of faba bean is the main hotspot. In OPC production, only around $20 \%$ of emissions are coming from oat cultivation.

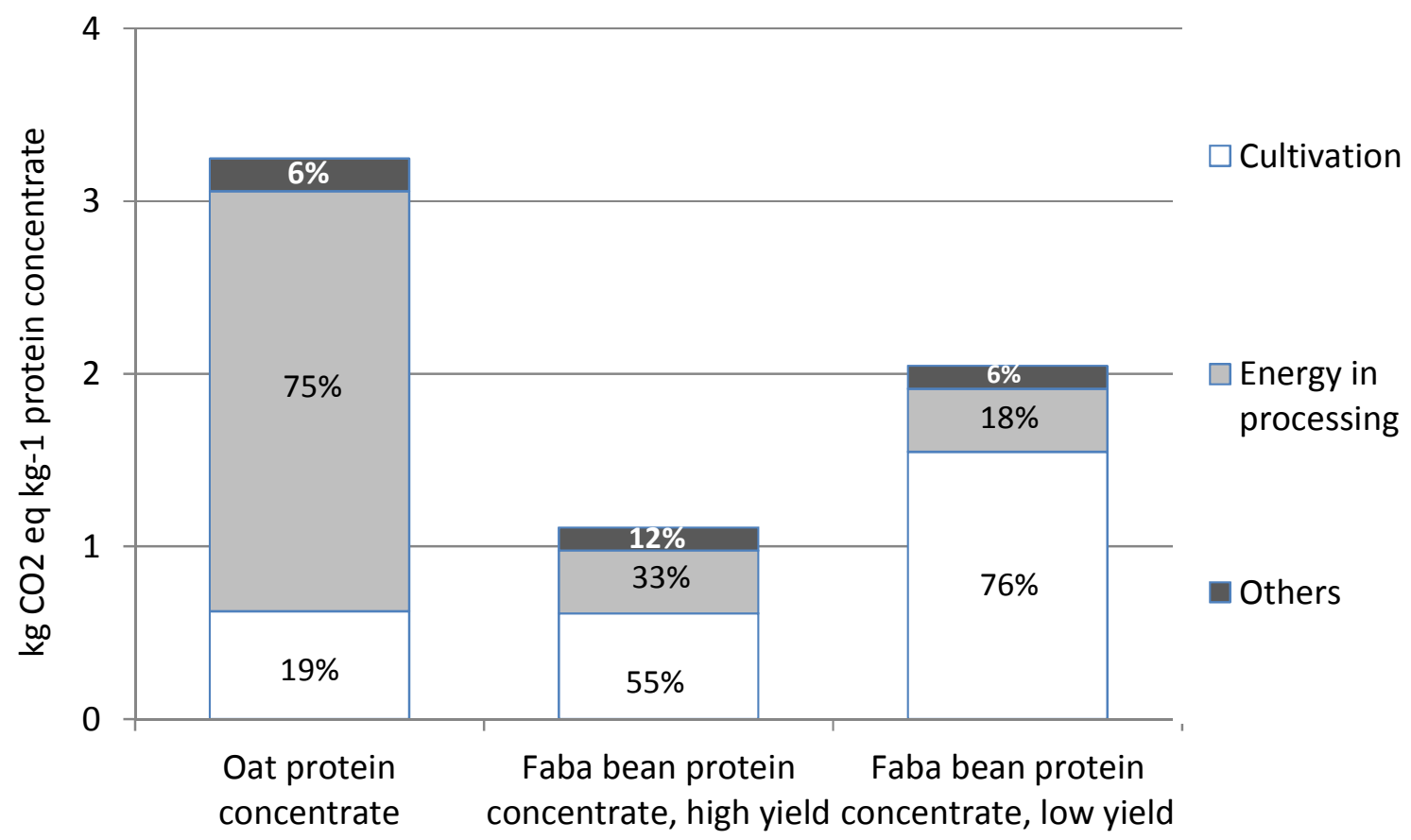


Figure 3. Carbon footprint of cradle-to-processing of oat protein concentrate (OPC) and faba bean protein concentrate $(\mathrm{FBC})$ divided into production chain phases. Others include transports and $\mathrm{CO}_{2}-$ production of processing.

\subsection{Sensitivity analysis}

As a consequence of using economic allocation, the prices of the single products will affect the environmental impacts that are allocated to the products. The question is how much significant changes in the prices can affect the carbon footprint of the OPC and thus, can they increase the carbon footprint so that the difference to animal protein is eliminated.

In addition, as the major hotspot in production of OPC is energy, sensitivity to emission intensity of electricity production was made. Instead of the average European emission factor, also emission factor describing Nordic countries (Nordel) was tested.

Impacts of prices used in allocation of the emissions of the OPC production on the carbon footprint are presented in Figure 4. If beta glucan or oat oil values are decreased drastically, by $50 \%$, the impact to the results is around $15-30 \%$. But if both are decreased simultaneously, the carbon footprint (or equally the land use) of OPC would increase by over $50 \%$. Also if the price of OPC is increased by $50 \%$, the impacts increase nearly $50 \%$, and if the price is doubled, then the impact is increased over $90 \%$. Thus, the results are very sensitive to the prices of OPC and quite sensitive also to prices of the different co-products.

The results are also sensitive to the emission intensity of electricity. The carbon footprint of OPC reduces nearly $20 \%$ when Nordic, instead of European average, emission factor is used.

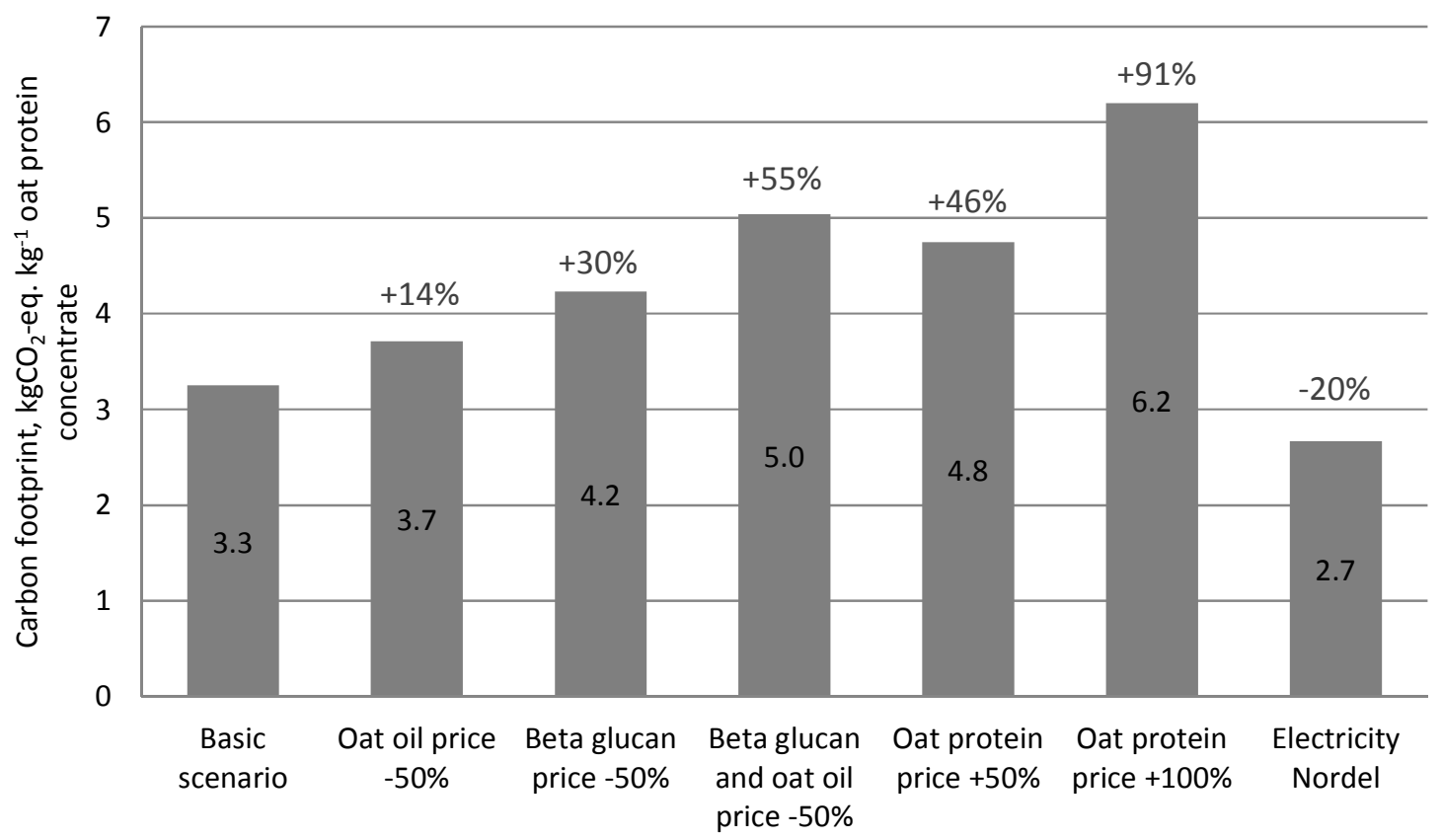

Figure 4. Sensitivity analysis results of oat protein concentrate production per $\mathrm{kg}$ OPC with different prices. 
As $75 \%$ of carbon footprint of OPC derives from energy consumption as such, also the amount of energy consumption has major impact on the carbon footprint. If the energy consumption of processing is changed $20 \%$, the carbon footprint changes by $15 \%$.

In case of land use, changes in energy consumption do not have any effect on the results, because only land use for oat cultivation is taken into account.

\section{Discussion}

\subsection{Comparison to other protein concentrates}

The carbon footprint per kg protein of OPC is less than half compared to dairy protein sources, such as skim milk powder or whey products (Table 9). Compared to carbon footprints published on soy protein isolate, OPC has $45 \%$ higher carbon footprint. However, it should be remembered that globally soy cultivation can cause land use changes and if soy has been cultivated on lately deforested land, the carbon footprint of soy isolate would be significantly higher than reported here if direct land use changes was included. Compared to other plant protein sources, which are dominating the market, e.g. pea and soy protein concentrates and wheat gluten, OPC has four times higher footprint (when no emissions from land use are expected for soy). This is probably due to the fact that only little processing is needed to reach high protein content concentrates from legumes and also legume cultivation requires very little nitrogen fertilizers as pulses have symbiotic $\mathrm{N}_{2}$ fixation and protein content is higher than of cereals.

The results show that faba bean protein concentrate has lower carbon footprint and land use than animal protein sources. According to statistics, faba bean yields have been increasing recently (FAOSTAT, 2017), which means that the high yield scenario could be more realistic, when it would have similar carbon footprint as pea or soy protein concentrates (when emissions from land use are not expected for soy). Carbon footprint of faba bean concentrate per kg protein is lower than oat protein concentrate. The difference is mainly due to the higher protein content of faba beans compared to oats, and much lower energy requirement in processing.

Usually the primary production (cultivation and animal production) is the major hotspot of food products. In the production of FBC, 55-76\% of the carbon footprint occurs in cultivation stage, depending on the high or low yield scenario. Similarly, in the production of wheat gluten, $46 \%$ occurs in cultivation stage and in production of soy protein concentrate $56 \%$, but in the case of OPC cultivation accounts for only around 19\%. In addition to the energy intensity of OPC production, this is also due to other more valuable side streams of OPC production to which most of the emissions from primary production are allocated. Thus, to reduce the environmental impacts of OPC production, the processing stage plays key role, while for FBC the cultivation stage is critical. 
Table 9. Comparison of carbon footprint of different protein sources.

\begin{tabular}{|c|c|c|c|c|}
\hline Product & $\begin{array}{c}\text { Carbon } \\
\text { footprint, } \\
\text { kg CO} \mathrm{CO}_{2} \text {-eq. } \\
\text { per kg } \\
\text { protein }\end{array}$ & $\begin{array}{l}\text { Protein } \\
\text { content, } \\
\%\end{array}$ & $\begin{array}{c}\text { Carbon } \\
\text { footprint, } \\
\text { kg } \mathrm{CO}_{2} \text {-eq. } \\
\text { per kg } \\
\text { product }\end{array}$ & Reference \\
\hline $\begin{array}{l}\text { Soy protein concentrate, } \\
\text { soybeans from USA }\end{array}$ & $1.8-2.0$ & $65-72$ & 1.3 & $\begin{array}{l}\text { Agri-footprint } \\
\text { database } 3.0\end{array}$ \\
\hline $\begin{array}{l}\text { Faba bean protein } \\
\text { concentrate (FBC) }\end{array}$ & 1.9-3.4 & 60 & $1.3-2.3$ & This study \\
\hline $\begin{array}{l}\text { Wheat gluten } \\
\text { (mass/economic } \\
\text { allocation }^{1} \text { ) }\end{array}$ & 2.1-3.4 & 75 & $1.6-2.6$ & Deng et al. 2013 \\
\hline Potato protein isolate & $2.2-2.6$ & 90 & & $\begin{array}{l}\text { Agri-footprint } \\
\text { database } 3.0\end{array}$ \\
\hline Pea protein concentrate & 2.2 & 55 & 1.3 & $\begin{array}{l}\text { Agri-footprint } \\
\text { database } 3.0\end{array}$ \\
\hline Wheat gluten meal & 2.8-4.1 & 80 & $2.5-2.9$ & $\begin{array}{l}\text { Agri-footprint } \\
\text { database } 3.0\end{array}$ \\
\hline $\begin{array}{l}\text { Soy protein isolate } \\
\text { (meta-analyses, } 10 \text { case } \\
\text { studies) }\end{array}$ & 6.1 & 87 & & Thrane et al. 2016 \\
\hline $\begin{array}{l}\text { Oat protein concentrate } \\
(\mathrm{OPC})\end{array}$ & 8.8 & 37 & 3.3 & This study \\
\hline $\begin{array}{l}\text { Soy protein concentrate, } \\
\text { soybeans from Brazil* }\end{array}$ & $9.3-10.3$ & $65-72$ & 6.7 & $\begin{array}{l}\text { Agri-footprint } \\
\text { database } 3.0\end{array}$ \\
\hline $\begin{array}{l}\text { Whey protein (meta- } \\
\text { analyses, } 3 \text { case studies) }\end{array}$ & 20.0 & 80 & 16.0 & Thrane et al. 2016 \\
\hline Whey protein concentrate & 20.5 & 80 & 16.4 & Flysjö et al. 2012 \\
\hline $\begin{array}{l}\text { Skim milk powder } \\
\text { (meta-analyses, } 3 \text { case } \\
\text { studies) }\end{array}$ & 23.0 & 35 & 8.1 & Thrane et al. 2016 \\
\hline Skim milk powder & 25.6 & 32 & 8.2 & Flysjö et al. 2012 \\
\hline Whole milk powder & 34.3 & 26 & 8.9 & Flysjö et al. 2012 \\
\hline
\end{tabular}

Opposite to climate change, oat protein concentrate has lower land use compared to faba bean concentrate, 8.6 versus $13-35 \mathrm{~m}^{2} / \mathrm{kg}$ protein. This is partly due to the fact that in OPC production process several co-products are produced and also due to the yield difference between oats and faba beans. Nijdam et al. (2012) have made a review on literature and provide following ranges for land use of different protein sources: pulses 10-43, milk 26-54, eggs $29-52$, poultry $23-40$ and pork $40-75 \mathrm{~m}^{2} / \mathrm{kg}$ protein. Thus, the land use requirement of OPC seems very low, whereas the land use of FBC falls exactly in the middle of the range for pulses.

\footnotetext{
${ }^{1}$ Mass allocation has been applied for allocating emission of multifunctional processing stage of wheat flour production and gluten separation to wheat flour and gluten. Generally in LCA, mass allocation is rarely a priority allocation method. In the study, economic allocation has been used as a sensitivity assessment. Generally in LCA, economic allocation is widely used when co-products have different purposes and properties.
} 
The results of this study indicate that OPC would be a climate friendly alternative to animal protein sources. However, it should be remembered, that the environmental impacts of OPC are very sensitive to the prices of the different products of its production system when economic allocation is used.

\subsection{Methodological uncertainties}

The current study only included two impact categories, carbon footprint and land use. The mitigation of greenhouse gasses, which is one of the main aims in valorizing all fractions of oats and faba beans, could be proved even with considering the energy consumption. Also benefits to land use compared to animal protein sources could be proved. Thus, it is expected that protein fractionation is beneficial also on other related impact categories, such as eutrophication or water depletion, but naturally, further assessment should be conducted also on other environmental impact categories sensitive to energy consumption, such as acidification, particulate matter and photochemical ozone formation.

Both certainty and accuracy of the allocation basis influence the uncertainty of the result. Allocating the impacts between the co-products of the production systems using market prices requires finding reliable price data sources. Still, even when expecting large changes in the prices, as was illustrated using sensitivity analyses, the main conclusion regarding environmental benefits of OPC compared to animal protein sources is valid. The expected

prices of oat oil and beta glucan are relatively high because of their use in cosmetics and health improving properties and relatively low market competition. Thus, these high prices and the relatively high yield of other co-products carry significant part of the overall environmental impacts and, as a result, the environmental performance of OPC is good.

In addition, if OPC production would be more common in the future, it could have significant influence on the prices of different fractions and thus, also environmental impacts, e.g. price of oat oil could decrease if the OPC production is increased and more oat oil would become available in market.

Data on energy consumption was from commercially operating plants, but OPC was produced as trial batch and is not commercially produced by the plants in question. Data provided showed that OPC production is currently very energy intensive, $5 \mathrm{MJ}$ of energy is needed to produce one $\mathrm{kg}$ OPC. In case of faba bean concentrate, the energy consumption is 3 $\mathrm{MJ}$ per kg faba bean protein concentrate, and in common wheat milling only $0.4 \mathrm{MJ}$ is used per kg flours (LCA Food database). Even though there are uncertainties in the energy consumption of novel processes, it is likely that in the future, the energy consumption would decrease and the electricity would be based on more renewable resources, instead of average European production mix used here. The production methods of new protein sources are still evolving, and the potential to reduce their environmental impacts is larger than in conventional animal production in Western countries (Smetana et al. 2015; Goldstein et al. 2017). Overall, to change the conclusion regarding environmental benefits of OPC compared to animal protein sources, the energy consumption should be more than double, which can be considered very unlikely if commercial production would take place. Rather, the opposite, 
reduction in energy consumption could be expected, and in addition, less emission intensive electricity could be used.

As Yao \& Masanet (2018) describe, there are major challenges in applying LCA to emerging technologies, mainly due to lack of reliable inventory data. Still, LCA together with sensitivity analyses of key parameters can provide meaningful insights to the magnitude of environmental impacts, hot spots and feasible improvement options. Despite the uncertainties and significant influence of key parameters on the results also in this study, the main conclusions of the study can be considered to be fairly robust, and it is clear where the future improvement measures should take place in the OPC and FBC production chains.

In the future, to ensure the robustness of the results, more environmental impact categories should be assessed, in particularly those which are affected by energy intensive processing stage. Furthermore, in this study the results were shown with two functional units: impact per $\mathrm{kg}$ product and per kg protein. Naturally, food products functional unit could be further detailed, considering differences in the digestibility of proteins and also other valuable nutrients. Particularly focus should be on those additional nutrients, which are important for protein products (Saarinen, et al. 2017). Protein concentrates are not ready-to-eat-foods as such, but they are used as ingredients in different food products, so comparison of OPC and FBC to foods rich in protein, like meats, is not adequate. Thus, the next step is to assess the environmental impacts of food products, e.g. bread and pasta, containing OPC and to compare the impacts with those of conventional food products. These food products can be used as part of a diet, where they can replace animal based proteins.

\section{Conclusions}

There is a need to find sustainable alternative protein sources in order to meet the increasing protein demand of the growing population. The study shows that faba bean protein concentrate has a carbon footprint comparable to pea and soy protein concentrates and lower than oat protein concentrate. This is mainly due to the lower amount of processing steps needed to reach high protein content concentrates from faba beans resulting mainly from relatively lower level of lipids, which enables more energy-efficient dry separation, and high initial protein content of legumes compared to cereals. Moreover, legume cultivation requires very little nitrogen fertilizers due to symbiotic $\mathrm{N}_{2}$ fixation.

However, land use is lower for oat protein concentrate compared to faba bean protein concentrate. Both faba bean protein concentrate and oat protein concentrate have lower carbon footprints compared to dairy proteins.

The major hotspots in the carbon footprints of the protein concentrates are different. For oat protein concentrate which is produced as a co-product from beta glucan production, energy consumption in processing is the hotspot, while for faba bean protein concentrate it is the cultivation stage.

It should be remembered, that the environmental impacts of oat protein concentrate are very sensitive to the prices of the different products of its production system: OPC, oat oil and beta 
glucan. By using economic allocation of the environmental burden, these high value products take the major share of the emissions of the energy intensive processing. Still, despite the uncertainties, the conclusions of the study can be considered adequately robust.

\section{Acknowledgements}

The work is part of the ERA-NET SUSFOOD OATPRO-project. This work was supported by Ministry of Agriculture and Forestry (MMM, Finland), the Federal Ministry of Education and Research, (BMBF, Germany), Romanian National Authority for Scientific Research and Innovation, (CCCDI-UEFISCDI, Romania) and Danish Agency for Science, Technology and Innovation (DASTI, Denmark).

Special thanks go to Prof. Kaisa Poutanen from VTT Technical Research Centre of Finland Ltd.

\section{References}

Alibaba 2018. www.alibaba.com. Last visited on $16^{\text {th }}$ August 2018

Anonym. 2011. Budgetkalkuler 2011. Online at:

https://www.landbrugsinfo.dk/oekonomi/budget/budgetkalkuler/

Anonymous, 2012. Farmtal Online. Available online at: www.farmtalonline.dk

Anonym. 2014. Vejledning om gødskning- og harmoniregler - Planperioden 1. august 2014 til 31. juli 2015. Miljø- og Fødevareministreiet, NaturErhvervstyrelsen on-line at:

http://naturerhverv.dk/landbrug/goedning/goedningsregnskab/

Audsley, E., Stacey, K, DJPaRSONS \& Williams, A. (2009). Estimation of the greenhouse gas emissions from agricultural pesticide manufacture and use. 10.13140/RG.2.1.5095.3122.

Bavarian State Research Institute for Agriculture. Düngemittelverordnung. Availabe online: $\underline{\text { www.lfl.bayern.de }}$

Blonk Agri-footprint BV. (2014). Agri-Footprint - Part 2 - Description of data - Version 1.0. Gouda, the Netherlands.

Carlsson-Kanyama, Gonzalez, Alejandro. 2009. Potential contributions of food consumption patterns to climate Change. Am J Clin Nutr 2009;89(suppl):1704S-9S.

Coda, R., Melama, L., Rizzello, C.G., Curiel, J.A., Sibakov, J., Holopainen, U., Pulkkinen, M. \& Sozer, N. 2015. Effect of air classification and fermentation by Lactobacillus plantarum VTT E-133328 on faba bean (Vicia faba L.) flour nutritional properties. International Journal of Food Microbiology 193 (2015) 34-42.

Dalgaard, T., Dalgaard, R., Nielsen, A.H. 2002. Energy use at organic and conventional farms. Grøn Viden Markbrug. No. 260. Danish Institute of Agricultural Science. 8 pp. (In Danish) Online at: http://web.agrsci.dk/djfpublikation/djfpdf/gvm260.pdf 
Danish Statistic. 2017. Dataudtræk fra http://www.statistikbanken.dk

Deng, Y., Achten, WMJ, Van Acker, K., Duflou, J. (2013) Life cycle assessment of wheat gluten powder and derived packaging film. Biofuels Bioproducts and Biorefining, 7(4):429458.

EC, 2013. The environmental footprint pilots. Online at:

http://ec.europa.eu/environment/eussd/smgp/ef_pilots.htm

EFSA NDA Panel (EFSA Panel on Dietetic Products, Nutrition and Allergies). 2012.

Scientific Opinion on Dietary Reference Values for protein. EFSA Journal 2012;10(2):2557, 66 pp. doi:10.2903/j.efsa.2012.2557

Elder M. 2017. Cattle Feed and Feed Additives: Global Markets to 2022, BCC Research, Report FOD074A, December 2017

European Commission 2013. The environmental footprint policy background. Online at: http://ec.europa.eu/environment/eussd/smgp/policy_footprint.htm

European Commission (2018) Product Environmental Footprint Category Rules Guidance. Version 6.3 - May 2018.

FAO. 2003. Fertilizer use by crop in Poland. Food and Agriculture Organization of the United Nations. Rome, 2003. 44 pages.

FAOSTAT. 2017. Crop statistics. Last Update February 13, 2017. Last visited May 3, 2017. Available online: http://www.fao.org/faostat/en/\#data/QC

FAOSTAT 2012. Faostat.fao.org. Assessed on $9^{\text {th }}$ June 2014

Finnagan T 2010. Food 2030 Life cycle analysis and the role of quorn foods within the new fundamentals of food policy. Summary document. Available at:

http://www.mycoprotein.org/assets/timfinniganfood2030.pdf

Flysjö, A. 2012. Greenhouse gas emissions in milk and dairy product chains improving the carbon footprint of dairy products. PhD Thesis. Science and Technology 2012. Aarhus University.

Frost\&Sullivan 2016a. North American Protein Ingredients Market, Forecast to 2020, K0D988, May 2016

Frost\&Sullivan 2016b. Analysis of the Western European Protein Ingredients Market, MC4A-88, September 2016

Goldstein B, Moses R, Sammons N, Birkved M (2017) Potential to curb the environmental burdens of American beef consumption using a novel plant-based beef substitute. PLoS ONE 12(12): e0189029. https://doi.org/10.1371/journal.pone.0189029 
IPCC. 2006. N2O Emissions from Managed Soils and CO2 Emissions from Lime and Urea Application (IPCC Chapter 11). pp. 1-54.

Jedwards International Inc. Oat oil. Last visited June 13, 2017. Available online:

https://bulknaturaloils.com/oat-oil.html

Kaukovirta-Norja A, Myllymäki O, Aro H, Hietaniemi V, Pihlava JM. 2008. Method for fractionating oat, products thus obtained, and use thereof [Internet]. Google Patents;

WO2008/096044 A1, 2008. Available from:

https://encrypted.google.com/patents/WO2008096044A1?cl=pt

Knudsen, M.T., Topp, K., Olesen, J.E., Hermansen, J.E., Schelde, K., Angelopoulos, N. \& Reckling, M. 2013. Energy and nutrient flows for the novel cropping systems - combined in a Life Cycle Assessment of grain legumes. Legume Futures Report D6.3.

KTBL. Online tool for the calculation of performance and costs. Association for Technology and Structures in Agriculture in Darmstadt. Available online:

http://daten.ktbl.de/dslkrpflanze/postHv.html;jsessionid=292DBB3694CC6F82B09B464524 A0645C

Marz U. 2013. Starches/Glucose: Global Markets, BCC Research, Report FOD037B, June 2013

Mulder, W., van der Peet-Schwering, C., Hua, N.-P., van Ree, R. 2016. Proteins for Food, Feed and Biobased Applications. IEA Bioenergy Task 42. Available at:

https://www.ieabioenergy.com/publications/proteins-for-food-feed-and-biobasedapplications/

Mäkinen, O., Sozer, N., Ercili-Cura, D., Putanen, K., 2016. Protein from oat: structure, processes, functionality, and nutrition. In: Nadathur, S., Wanasundara, J.P.D., Scanlin, L. (Eds) Sustainable Protein Sources, pp. 105-119.

Nehete, J.Y., Bhambar, R.S., Narkhede, M.R., Gawali, S.R., 2013. Natural proteins: Sources, isolation, characterization and applications. Pharmacogn Rev. 7(14): 107-116.

Nielsen, O.K., Plejdrup, M.S., Winther, M., Nielsen, M., Gyldenkærne, S., Mikkelsen, M.H., Albrektsen, R., Thomsen, M., Hjelgaard, K., Hoffmann, L., Fauser, P., Bruun, H.G., Johannsen, V.K., Nord-Larsen, T., Vesterdal, L., Møller, I.S., Caspersen, O.H., Rasmussen, E., Petersen, S.B., Baunbæk, L., Hansen, M.G. 2014. DENMARK'S NATIONAL INVENTORY REPORT 2014, Emission Inventories 1990-2012 - Submitted under the United Nations Framework Convention on Climate Change and the Kyoto Protocol. Scientifi c Report from DCE - Danish Centre for Environment and Energy No 101. 1226 pp.

Nijdam, D., Rood, T. \& Westhoek, H. 2012. The price of protein: Review of land use and carbon footprints from life cycle assessments of animal food products and their substitutes. Food Policy 37 (2012) 760-770. 
Notarnicola, B., Sala, S., Anton, A., McLaren, S.J., Saouter, E., Sonesson, U., 2017. The role of life cycle assessment in supporting sustainable agri-food systems: A review of the challenges. Journal of Cleaner Production 140, 399-409.

Nowson, C. and O'Connell, S. (2015) Protein Requirements and Recommendations for Older People - a review. Nutrients 7, 6874-6899.

Pierer, M., Winiwarter, W., Leach, A. \& Galloway; J. 2014. The nitrogen footprint of food products and general consumption patterns in Austria. Food Policy Volume 49, Part 1, December 2014, Pages 128-136.

Ponsioen, T. 2014. Updated Carbon Footprint Calculation Factors. March 12, 2014. Available online: https://www.pre-sustainability.com/news/updated-carbon-footprintcalculation-factors

Reijnders, L. \& Soret, S. 2003. Quantification of the environmental impact of different dietary protein sources. The American Journal of Clinical Nutrition vol. 78 no. 3 (2003) 6645-6685

Saarinen, M.; Fogelholm, M.; Tahvonen, R.; Kurppa, S. (2017) Taking nutrition into account within the life cycle assessment of food products. Journal of Cleaner Production 149: 828844.

Smetana S., Mathys A., Knoch A., Heinz V. 2015. Meat alternatives: life cycle assessment of most known meat substitutes. Int J Life Cycle Assess. 20:1254-1267. DOI 10.1007/s11367-

015-0931-6

Sozer, N., Ercili-Cura, D., Nordlund, E., Poutanen, K. (2017a) Cereal side-streams as alternative protein sources. Cereal Foods World 62(4), 132-137.

Sozer, N., Holopainen-Mantila, U., \& Poutanen, K. (2017b). Traditional and New Food Uses of Pulses. Cereal Chemistry, 94(1), 66-73.

Statistics Germany. 2014. Hektaretrag Statistisches Bundesamt Fachserie 3 Reihe 32014 Seite 5

Thrane, M., Paulsen, P.V., Orcutt, M.W. \& Krieger, T.M. 2016. Chapter 2 - Soy Protein: Impacts, Production, and Applications. In: Nadathur, S., Wanasundara, J.P.D. \& Scanlin, L. (eds.). 2014. Sustainable Protein Sources. $1^{\text {st }}$ Edition. Pages 23-45.

Tempo database. The National Institute of Statistics. Romania. Available online: http://www.insse.ro/cms/

Tukker A, Jansen B. 2006. Environmental impacts for Products. J Ind Ecol. 10(3):159-182.

WCRF (2017) Diet, nutrition, physical activity and colorectal cancer. Continuous update project report. World Cancer Research Fund International (WCRF)/American Institute for Cancer Research. Available at http://www.wcrf.org/colorectal-cancer-2017 
Xue X, Landis AE. 2010. Eutrophication potential of food consumption patterns. Environ Sci Technol. 44(16):6450-6. DOI: 10.1021/es9034478

Yao Y, Masanet E. 2018. Life-cycle modeling framework for generating energy and greenhouse gas emissions inventory of emerging technologies in the chemical industry. Cleaner Production 172:768-777. 